\title{
Organising an Alternative University: A Reflection on the Conference 'Critical, Emancipatory and Solidarist Endeavors'
}

\author{
Sarah Amsler \\ University of Nottingham, Nottingham, UK, sarah.amsler@nottingham.ac.uk
}

\begin{abstract}
This article presents a report on the international conference 'Beyond University: Critical, Emancipatory and Solidarist Endeavors', organised by the Kocaeli Dayanışma Akademisi (Kocaeli Academy for Solidarity) in Kocaeli, Turkey on 30-31 March 2018. At the time of writing, its organisers and many of their colleagues and students remain dismissed from their university positions and under threat of state violence and repression. They are also, however, active in organising autonomous higher education courses and research in the interest of advancing intellectual, social and ecological emancipation in Turkey and beyond. This work is important not only within Turkey, but also for ongoing transnational debates about the geography and nature of struggles for a liberatory higher education, as well as the radical imagination of what else the university is and can be.
\end{abstract}

Keywords: academic labour, Academics for Peace, alternative academy, university politics

Acknowledgement: Many thanks to Derya Keskin for her thoughtful comments on and critiques of earlier drafts of this work.

There are many front lines in the globalised struggle for liberation and dignified living today. All face a common enemy in the convergence of conservative, authoritarian and fascistic state regimes on the one hand, and the relentless consolidation of power in an aggressive capitalist rationality that commodifies, marketizes and disposes of life in pursuit of endless accumulation on the other. Across Europe, this conjuncture is palpable in the empowerment of far-right organisations and political parties (The Economist 2017), the legitimisation of racist and misogynist social behaviour (Abbott 2017), the impunity of transnational corporations (Bah 2018), the normalisation of institutional calculation and coldness (Morrish 2017), the resurgence of crude nationalism and colonialist separatism (Younge 2018), the fragmentation of communities of resistance and care, and the closing of spaces for transformative thought and practice.

In these dark times in which neoliberalism and fascism govern arm in arm (Goldfarb 2018; Foster 2017), the question of the university - the role of critical scholarship and scholarship in social liberation - is urgent. It has long been argued that the liberal university is 'in crisis' and that other ways of organising education and research are necessary. In the Anglosphere, critiques of the corporate university extend back nearly a century, with books like The Higher Learning in America (Veblen 1918) foreshadowing Warwick University, Ltd. (Thompson 1970), The University in Ruins (Readings 1997) and Academic Capitalism and the New Economy: Markets, State and Higher Education (Rhoades and Slaughter 2004). More recently, transnational analyses of the "neoliberal university' have proliferated in academic and activist discourses as part of a 'globalising' alter-university movement that connects struggles for critical, autonomous and transformative knowledge production with struggles for decent, self-governing and possibility-affirming life. Some of these struggles are within and against the universityas-it-is in its authoritarian, bureaucratic and capitalist forms; others are located at "new 
spatial-temporal coordinates for the production of oppositional knowledges and the organization of living knowledge's autonomy" (EduFactory Collective 2009, 11). As these ways of knowing stretch further towards a fully decolonized future, academics, scholars, students and - in the words of Gustavo Esteva - "deprofessionalised intellectuals" are asserting that another university is possible (Piaget-Clarke 2005; Emejulu 2017).

While this discourse of globalised struggle is important for connecting learning and resistances across borders, however, it risks subsuming local circumstances under general critiques of authoritarian neoliberalism or neoliberal authoritarianism. This erosion of the local and the particular obscures awareness of the different ways that social forces take shape within, and intersect with, local and national histories, political economies, logics of social governance, intellectual traditions, and cultural and political forms. This has significant implications not only for understanding the constraints on critical knowledge production and educational practice today, but also for conceptualising the possibilities of critique, alterity and resistance in emancipatory academic work. Greater visibility of this complexity within the alter-university movement, on the other hand, reveals a range of methods for creating and defending emancipatory knowledge which are already being used today.

Sharing these experiences in order to build solidarity across borders and generations was the theme of the international conference Beyond the University: Critical, Emancipatory and Solidarist Endeavours, organised by the Kocaeli Dayanişma Akademisi (Kocaeli Academy for Solidarity, or KODA) in Turkey in March 2018 (Kocaeli Academy for Solidarity 2018). While the title of the conference resonated with many other 'reimagining-the-university' gatherings that have been organised elsewhere in recent years, and for this reason invited solidarity from scholar-activists based in Italy, Japan, Poland and the UK, the urgency of understanding what sustains critical, emancipatory and solidarity intellectual work beyond the university was particularly acute for the conference organisers.

The commodification, privatisation and marketization of an already-unequal higher education system in Turkey has created, as in other countries, problems and sources of crisis for decades (Aslan 2014). After the conservative Justice and Development Party (AKP) came to state power, however, these trends intersected with agendas to Islamicise Turkish public institutions on the one hand and secure Turkey's membership in the European Union on the other, against a backdrop of ongoing conflict with and repression of Kurdish groups and communities within the territory. The regime has adopted increasingly authoritarian methods to reconstruct state and society towards these ends, and to discipline workers, intellectuals and students who question and dissent from the system. In higher education, "it can hardly be claimed that universities in Turkey have ever enjoyed academic autonomy, but this situation has worsened since 2002 under the regime of the Justice and Development Party (AKP)" (Bakirezer, Keskin Demirer and Yeşilyurt 2018), with state-appointed university rectors empowered to appoint deans, department heads and academics "who are ideologically affiliated with the government rather than choosing people based on merit" (Bakirezer, Keskin Demirer and Yeşilyurt 2018).

It was in this cramped context that Academics for Peace was established in 2012, in order to "work for a peace process in Turkey and to contribute to it by producing knowledge and information on topics like processes of peace and conflict, practices of peace-making, women's role in the peace process, education in native languages and the destruction of the environment through war" (Barış Için Akademisyenler 2018). In 2016, however, the conditions for scholar-activists deteriorated further after an attempted coup against the regime prompted the collective punishment and purging of 
public servants including university academics and administrators, teachers, journalists, health workers and trade unionists who were accused of "propagandizing for a terrorist organization" (Baser, Akgönül and Öztürk 2017, 275). Thousands of people were arrested, imprisoned, dismissed from their posts, blacklisted from professional life and denied the right to travel outside the country (Bendix 2017). Among them were four 'Peace Academics' who were initially imprisoned for over a month and then released. Since that time, academics from universities across the country who had signed a petition - "We will not be a party to this crime!" - demanding an end to state violence in Kurdish settlements and the creation of "a road map that would lead to a lasting peace which includes the demands of the Kurdish political movement" (Academics for Peace 2016; Tanık 2018) have been dismissed from the universities, facing what Academics for Peace call a "civil death" constructed "through the cooperation of the government, the commission of higher education and university managements". At the same time, academics monitoring the prison population in the country estimate that at least 70,000 students are also now in prison or charged with offences of "terrorism" and "insulting the president" (Stockholm Center for Freedom 2018).

During the Beyond University conference, the method for responding to these problems was clear: they must be answered while walking towards alternatives, through praxis. When there is no 'outside', when you can't be 'inside' and when power doesn't sleep, all forms and sites of struggle afford different constellations of possibility. Interrupt, build commons, defend - wherever you are, wherever you can - and work to keep all spaces of possibility alive. This was not only a theoretical position, but an historical lesson as well. The history of academic and educational repression in Turkey is also a history of self-organised learning that is dedicated to producing, disseminating and activating emancipatory knowledge outside the university fences and in the service of social freedom (Alyanak 2018). Although the conference aimed to strengthen solidarity among the recently formed 'Solidarity Academies' and their allies (Dayanışma Akademileri n.d.), it was attended by veteran scholar-activists who had themselves established autonomous associations during previous periods of struggle. This included organisations founded by academics, intellectuals and professionals after a military coup in September 1980, such as the Free University - Institute for Middle East Studies (Özgür Üniversite, founded in 1984), the Human Rights Association (IInsan Hakları Derneği, founded in 1986) and critical study associations like Bilsak and Bilar, as well as 21st-century organisations like the Social Research Foundation (Sosyal Araştırmalar Vakf, founded in 2000) and Human Rights Academy (İnsan Hakları Akademisi, founded by the Human Rights Association in 2008).

One presently dis-employed academic remembered that after a previous period of professional exile, a law was passed allowing academics to return to their university posts. Yet this victory also made it hard to remain active and solidary with the nonacademic associations that had emerged during the crisis. A younger scholar affected by the most recent purge agreed, saying, "I wish there had been a network of Solidarity Academies before all these things happened". Another pleaded for teachers, researchers and administrators who still hold university positions to occupy the institutions as sites of struggle and possibility, and to keep spaces open for those who seek to return. Feminist researchers reminded us that critical fields such as women's studies had originally emerged from the streets and must stay on them if academics are to resist depoliticising processes of professionalisation, marketization and political terrorisation. Those working outside the university, however, pointed out that working beyond the university is also no easy ride in authoritarian and capitalist societies, where even human rights activism has been opened to the market and state surveillance. In other 
words, while the university-in-exile is in one sense a network of temporary autonomous learning zones, it also plays an important role in sustaining general possibilities for public scholarship and dissent.

The second day of the conference explored the epistemological, pedagogical and methodological character of these critical spaces. Speakers illustrated how struggles to legitimise knowledge produced through non-positivist research is an essential part of today's struggles to create other social and material worlds. Learning must be embedded in and emergent from everyday life; we must be able to ask new kinds of questions that cannot yet be apprehended or imagined from within existing empirical realities, and to overcome the separations and alienation that prevents us from seeing beyond these constraining horizons of possibility. Feminist methodologies had much to offer here, with their will to make the unseen visible and to assert epistemic justice for those people, knowledges and possibilities whose existence is rendered unintelligible by domination. Such epistemologies of possibility call for approaches to teaching and learning that embrace transformative dialogue, pedagogical curiosity, non-dominating forms of communication, and valuations of learning that do not reduce creative processes to metrics and measurements.

Above all, we were reminded that this work cannot be a professional exercise that advances the continuation of the universities-as-they-are. It is rather only through commoning that we can construct both new realities and the conditions of life to support them. This work begins from emancipatory learning - not from the preservation of institutions that alienate such activity through controlling, containing and destroying it (Hall 2018). It is not sufficient to desire 'alternatives' to existing university systems in Turkey and throughout the world. The question is not whether non-capitalist, democratic and justice-committed forms of higher education and knowledge production are possible. In Turkey alone, the Solidarity Academies, autonomous scholarly organisations, nongovernmental organisations and informal learning associations that sustain the academy beyond state and market domination are proof enough that they are. So, too, are other examples of mass intellectuality (Hall 2014) that were shared during the conference, of Marxist scholarship that flourishes by creatively subverting neoliberal systems of measurement and value (Praktyka Teoretyczna 2018), of a democratically student-directed university that thrives in Japan's "diploma-oriented" society (Li 2017), of longitudinal projects to connect radical education movements across the world amidst changing conditions of possibility under global capitalism (Edufactory Collective 2009). The better question is rather what forms of organisation are most appropriate to facilitate the kind of emancipatory knowledge and political subjectivities that are needed by free societies and societies in movement in particular places around the world today (Gavroche 2017).

When the conference ended, international visitors went home; the dismissed academics remained unemployed, "without campus" (Kampüssüzler 2018), on trial and under threat; and their students remained detained. Yet in restaurants, meeting halls, homes and the streets (Free Speech Radio News 2017), emancipatory teaching and research for dignity, justice and freedom resumed without interruption. We can recognise them, as Richard Hall argues, as "struggles both inside and outside of the university, to build counter-hegemonic positions rooted in solidarity and sharing, and related to the social and co-operative use of the knowledge, skills and practices that are created by labour, might be analysed in terms of mass intellectuality" (Hall 2018; Hall and Winn 2017). For as Derya Keskin Demirer explained in a post-conference interview, 
[W] we were [forced] out of university, but the university practice as we understand it $[. .$.$] is not finished for us. We are still academics, we are still doing research$ and we are still getting together with our students. This means that that the university is nowhere between four walls; there is not just something compressed there. We can create our own university outside the walls of the university. It does not have to be called a university. But that does not mean we're giving up college. In this sense, the quest is perhaps no longer for what is called 'the university', but a search for a university that is beyond universities (Keskin Demirer, quoted in Tangün 2018).

The struggle to return the academy to the universities and to return the universities to the people continues in, against and beyond institutions and as part of a larger project to reclaim the general commons (Wittel 2016). Liberatory educators and alternative world-makers across the world have much to learn from it.

\section{References}

Abbott, Diane. 2017. I fought racism and misogyny to become an MP. The fight is getting harder. The Guardian, February 14. Accessed 13 May 2018. https://www.theguardian.com/commentisfree/2017/feb/14/racism-misogyny-politics-online-abuse-minorities

Academics for Peace. 2016. We will not be a party to this crime! [Petition]. Accessed 13 May 2018. https://barisicinakademisyenler.net/node/63

Alyanak, Oguz. 2018. Terrorist students, terrorist academics. Anthropology News, April 24. Accessed 13 May 2018. http://www.anthropology-news.org/index.php/2018/04/24/terrorist-students-terrorist-academics/

Aslan, Gülay. 2014. Neo-liberal transformation in Turkish higher education system: A new story of a turning point: Draft proposition on the higher education law. Journal for Critical Education Policy Studies 122: 255-283. Accessed 13 May 2018. http://www.jceps.com/wp-content/uploads/2014/08/9-JCEPS122-guas-FINAL14-July2014.pdf

Bah, Valerie. 2018. Feminist activists speak out against corporate impunity [Video]. OpenDemocracy, March 16. Accessed 13 May 2018. https://www.opendemocracy.net/valeriebah/video-feminist-activists-corporate-impunity-binding-treaty

Bakirezer, Güven, Derya Keskin Demirer and Adam Yeşilyurt. 2018. In Pursuit of an Alternative Academy: The case of Kocaeli Academy for Solidarity. tripleC: Communication, Capitalism \& Critique 16 (1): 234-240. Accessed 13 May 2018. https://www.triple-c.at/index.php/tripleC/article/view/894

Barış İçin Akademisyenler. 2018. Academics for Peace [Website]. Accessed 13 May 2018. https://barisicinakademisyenler.net/node/1

Baser, Bahar, Samim Akgönül and Ahmet Öztürk 2017. 'Academics for Peace' in Turkey: A case of criminalising dissent and critical thought via counterterrorism policy. Critical Studies on Terrorism 102: 274-296.

Bendix, Aria. 2017. Turkey dismisses thousands of police, civil servants and academics. The Atlantic, 14 July. Accessed 13 May 2018. https://www.theatlantic.com/news/archive/2017/07/turkey-dismisses-thousands-of-police-civil-servants-and-academics $/ 533754 /$

Committee of Solidarity Academies. 2018. Call from Solidarity Academies. International Journal of Health Services 482: 378-379.

Dayanişma Akademileri. n.d. Solidarity Academies website. Accessed 13 May 2018. https://www.dayanismaakademileri.org/

Edufactory Collective. 2009. Towards a Global Autonomous University. Williamsburg, NY: Autonomedia. Accessed 13 May 2018. https://libcom.org/files/The\%20Edu-factory\%20Collection\%20-\%20Toward\%20a\%20Global\%20Autonomous\%20University\%20- 
\%20Cognitive\%20Labor,\%20The\%20Production\%20of\%20Knowledge,\%20and\%20Exodus\%20from\%20the\%20Education\%20Factory.pdf

Emejulu, Akwugo. 2017. Another university is possible. Verso Press [Blog], January 12. Accessed 13 May 2018. https://www.versobooks.com/blogs/3044-another-university-is-possible

Foster, John Bellamy. 2017. This is not populism. Monthly Review 692. Accessed 13 May 2018. https://monthlyreview.org/2017/06/01/this-is-not-populism/

Free Speech Radio News. 2017. Turkish academics fired in ongoing purges to take their coursework to the streets, March 29. Accessed 13 May 2018.

https://fsrn.org/2017/03/turkish-academics-fired-in-ongoing-purges-take-their-courseworkto-the-streets/

Gavroche, Julius. 2017. Autonomy as societies in movement? Raul Zibechi. Autonomies. Accessed 13 May 2018. http://autonomies.org/2017/11/autonomy-as-societies-in-movementraul-zibechi/

Goldfarb, Jeffrey. 2018. Women and men in dark times (syllabus included). The New School, 29 January. Accessed 13 May 2018. http://www.publicseminar.org/2018/01/women-andmen-in-dark-times-syllabus-included/

Hall, Richard. 2018. On the Alienation of Academic Labour and the Possibilities for Mass Intellectuality. tripleC: Communication, Capitalism \& Critique, 16 (1): 97-113. Accessed 13 May 2018. https://www.triple-c.at/index.php/tripleC/article/view/873

Hall, Richard. 2014. On the Abolition of Academic Labour: The Relationship between Intellectual Workers and Mass Intellectuality. tripleC: Communication, Capitalism \& Critique 12 (2): 822-837. Accessed 13 May 2018. https://www.triple-c.at/index.php/tripleC/article/view/597

Hall, Richard and Joss Winn, eds. 2017. Mass Intellectuality and Democratic Leadership in Higher Education. London: Bloomsbury Press.

Human Rights Association. 2008. History of Human Rights Association. Accessed 13 May 2018. http://ihd.org.tr/en/index.php/2008/12/08/history-of-human-rights-association-ihd/

Kampüssüzler. 2018. Kampüssüzler Facebook page. Accessed 13 May 2018. https://www.facebook.com/Kampussuzler/

Kocaeli Academy for Solidarity. 2018. Critical, Emancipatory and Solidarist Endeavors [Conference]. Kocaeli, Turkey, March 30-31. Accessed 13 May 2018. https://www.kocaelidayanisma.org/wp-content/uploads/2018/03/KODA Konf EN-TR PROGRAM.pdf

$\mathrm{Li}$, Yan. 2017. Shure: A democratic university in Tokyo. Alternative Education Resource Organization. Accessed 13 May 2018. http://www.educationrevolution.org/store/shure-ademocratic-university-in-tokyo/

Morrish, Liz. 2017. Why the audit culture made me quit [Blog post]. World.edu: global education network, March 2. Accessed 13 May 2018. http://world.edu/audit-culture-made-quit/

Özgür Üniversite 2018. Özgür Üniversite [Website]. Accessed 13 May 2018. http://ozguruniversite.org/

Piaget-Clarke, Nic. 2005. Interview with Gustavo Esteva: The society of the different. In Motion magazine, September. Accessed 13 May 2018. http://www.inmotionmagazine.com/global/gest int $1 . \mathrm{html}$

Praktyka Teoretyczna. 2018. About page [Journal website]. Accessed 13 May 2018. http://www.praktykateoretyczna.pl/english/about/

Readings, Bill. 1997. The University in Ruins. Cambridge, MA: Harvard University Press.

Rhoades, Gary and Sheila Slaughter. 2004. Academic capitalism in the new economy: Challenges and choices. American Academic 1 (1): 37-59. Accessed 13 May 2018. http://firgoa.usc.es/drupal/files/Rhoades.qxp.pdf

Sosyal Arastirmalar Vakfi. n.d. Ana sayfa [Homepage, website]. Accessed 13 May 2018. http://savportal.org/index.php?lang=en

Stockholm Center for Freedom. 2018. 70,000 students behind bars in Turkey. April 10. Accessed 13 May 2018. https://stockholmcf.org/70000-students-behind-bars-in-turkey/ 
Tangün, Yağız Alp. 2018. Kocaeli'den dünyaya: Üniversite ötesinde bir arayış. SUSMA Platform, April 16. Accessed 13 May 2018. http://susma24.com/kocaeliden-dunyaya-universite-otesinde-bir-arayis/

Tanık, Feride Aksu. 2018. The price of demanding peace: The case of Academics for Peace in Turkey. International Journal of Health Services, 482: 371-377.

The Economist. 2017. Europe's populists are waltzing into the mainstream. February 3. Accessed 13 May 2018. https://www.economist.com/news/briefing/21736137-they-and-theirideas-are-both-being-picked-up-established-parties-europes-populists-are

Thompson, Edward Palmer. 1970. Warwick University, Ltd. London: Penguin Books.

Veblen, Thorstein. 1918. The Higher Learning in America: A Memorandum of the Conduct of Universities by Business Men. Accessed 13 May 2018. http://la.utexas.edu/users/hcleaver/330T/350kPEEVeblenMemoUnivEditTable.pdf

Wittel, Andreas. 2016. Higher education as a gift and as a commons. tripleC: Communication, Capitalism \& Critique 16 (1): 194-213. Accessed 13 May 2018. https://www.triplec.at/index.php/tripleC/article/view/892

Younge, Gary. 2018. Britain's imperial fantasies have given us Brexit. The Guardian, February 3. Accessed 13 May 2018. https://www.theguardian.com/commentisfree/2018/feb/03/imperial-fantasies-brexit-theresa-may

\section{About the Author}

\section{Sarah Amsler}

Sarah Amsler is Associate Professor in Education at the University of Nottingham, a member of the Social Science Centre educational co-operative in Lincoln, UK, a member of the Ecoversities network and a mother. Her scholarly work centres on understanding and creating epistemic, ontological, affective and pedagogical resources for liberation from oppressive systems including capitalism, heteropatriarchy and coloniality. She is especially interested in how affective pedagogies and methods of inquiry into the 'not-yet' possible can open processes of 'learning and organising hope', and in co-creating spaces for such processes to become possible both in formal institutions (schools and universities) and in the creation of local and transnational communities. A sociologist and educator, she teaches inside and outside the university in the areas of education and social justice, critical social theory, practice-based research and research methodology and contributes to popular education projects. 